Tohoku J. exp. Med., 1972, 106, 399-409

\title{
A Case of Thrombasthenia with a Study of Platelet Aggregation by Hydrogen Peroxide $\left(\mathrm{H}_{2} \mathrm{O}_{2}\right)$
}

\author{
Ototaka Higashi, Yoko Kikuchi and Kimitchi Konno \\ Department of Pediatrics, Akita University School of Medi- \\ cine, Akita
}

Higashi, O., KrkUChI, Y. and Konno, K. A Case of Thrombasthenia with a Study of Platelet Aggregation by Hydrogen Peroxide $\left(\mathrm{H}_{2} \mathrm{O}_{2}\right)$. Tohoku J. exp. Med., 1972, 106 (4), 399-409 — A six-year-old girl with a congenital hemorrhagic disorder characteristic of thrombasthenia or Glanzmann's disease was reported. $A$ special study on platelet aggregation was performed. It was found that patient's platelets failed to aggregate in response to hydrogen peroxide $\left(\mathrm{H}_{2} \mathrm{O}_{2}\right)$, while normal platelets were readily aggregated by this agent. This $\mathrm{H}_{2} \mathrm{O}_{2}$ induced aggregation of normal platelets can be inhibited by adenosine, suggesting a possible mechanism that $\mathrm{H}_{2} \mathrm{O}_{2}$ might stimulate platelets to release ADP, which in turn causes platelet aggregation. ___ thrombasthenia; platelet aggregation by hydrogen peroxide

Thrombasthenia or Glanzmann's disease is the hemorrhagic state which is characterized by a congenital bleeding tendency with normal platelet count, long bleeding time, variably deficient clot retraction and absent platelet aggregation.

The fundamental defect in this condition appears to be the inability of platelets to aggregate in response to adenosine diphosphate (ADP) (Hardisty et al. 1964, Caen et al. 1966, Zucker et al. 1966, and Corby et al. 1971).

The purpose of the present paper is to describe a case with thrombasthenia and to report the results of a study on the platelet aggregation induced by a new aggregating agent, hydrogen peroxide $\left(\mathrm{H}_{2} \mathrm{O}_{2}\right)$.

\section{Case Report}

The present case (S.C.) was referred to the Akita University Hospital for the study of her hemorrhagic tendency. The early history revealed that a prolonged umbilical bleeding was encountered at birth. At 3 years of age, she had a profuse bleeding from mouth following trauma. Since then she had had frequent petechiae, ecchymoses and epistaxis, sometimes necessitating blood transfusions.

The family history revealed that the parents are unrelated. Neither parents nor two younger sisters of the present patient had symptoms suggesting hemorrhagic diathesis. A cousin of the paternal grandfather died of a hemorrhagic diathesis of unknown nature.

The physical examination on admission revealed a well developed and well nourished 6-year-old girl with new and old petechiae scattered over the entire

Received for publication, October 1, 1971. 
kody, but with no other marked findings.

During a period of about 3 months of hospitalization, she has had frequent episodes of nose bleed, which were controlled by local hemostatic measures.

\section{Laboratory Findings}

$\mathrm{RBC}$ was 3.96 millions per $\mathrm{mm}^{3}$, hemoglobin $11.2 \mathrm{~g}$ per $100 \mathrm{ml}$, hematocrit $34 \%$, reticulocytes $12 \%$, WBC 5,800 per $\mathrm{mm}^{3}$. Differential counts and morphology of leucocytes were normal. Other normal laboratory data included serum protein, serum electrolytes, serum GOT and GPT, alkaline and acid phosphatases and lactic dehydrogenase. A microscopic hematuria and a positive fecal occult blood test were encountered sometimes.

Bleeding, coagulation and platelet studies

The bleeding time (Duke) was prolonged, being 32 minutes. The RumpelLeede test was positive. The platelet count (Rees and Ecker) was normal, being 270,000 per $\mathrm{mm}^{3}$. In stained blood smears, almost no platelet clumping was seen. The nuclear segmentation of megakaryocytes in bone marrow (Higashi et al. 1971) was within normal limits, the lobe average being 1.05 .

The blood coagulation studies, including recalcification time, partial thromboplastin time (PTT), Kaolin-PTT, prothrombin time (Quick) and thrombotest (Owren) were all within normal limits. The thromboplastin generation tests (Biggs and Macfarlane 1957) using patient's own platelets, deprothrombinized plasma and serum, also gave rise to the entirely normal results. The activity of Factor XIII (Barrey et al. 1965) was normal. Plasma fibrinogen was $260 \mathrm{mg}$ per $100 \mathrm{ml}$. The clot retraction (Didisheim 1967) appeared to be within normal limits, being 75. In the thromboelastrogram, however, a prolongation of $k$ and decreases of $m a$ and $m \varepsilon$ values were evident (cf. Table 1). Adhesivenss of platelets on glass surface (Tanaka 1957) was reduced (cf. Table 1).

The results of the platelet aggregation studies (Corby et al. 1971) were grossly

TALBE 1. Evaluation of platelet status of the present patient and her parents

\begin{tabular}{|c|c|c|c|c|}
\hline & Patient & Mother & Father & Normal control \\
\hline Bleeding time (min) & 32 & 3 & 2 & $1-6$ \\
\hline Platelet count/cmm & 270,000 & 177,000 & 213,000 & $150,000 \sim 450,000$ \\
\hline Platelet adhesion, \% & 0 & 27 & 40 & $26-34$ \\
\hline $\begin{array}{c}\text { Platelet aggregation, \%* } \\
\text { APD }\end{array}$ & $5-10$ & 41-93 & & \\
\hline Collagen & 2 & 37 & $\begin{array}{r}02-01 \\
55\end{array}$ & $\begin{array}{c}69-97 \\
67\end{array}$ \\
\hline $\begin{array}{c}\mathrm{H}_{2} \mathrm{O}_{2} \\
\text { Thrombelastogram }\end{array}$ & $2-4$ & $37-50$ & $13-18$ & $20^{-} 67$ \\
\hline$r(\min )$ & 10.5 & 10.5 & 10,8 & $9-13$ \\
\hline$k(\min )$ & 10.0 & 4.5 & 4.5 & $4-6$ \\
\hline$m a(\mathrm{~mm})$ & 38.0 & 55.5 & 52.5 & $49-61$ \\
\hline$m \varepsilon(\%)$ & 61.3 & 124.5 & 110.5 & $96-156$ \\
\hline
\end{tabular}

* The maximum per cent aggregation of platelets observed during a period of six minutes after the addition of the aggregating agent. 


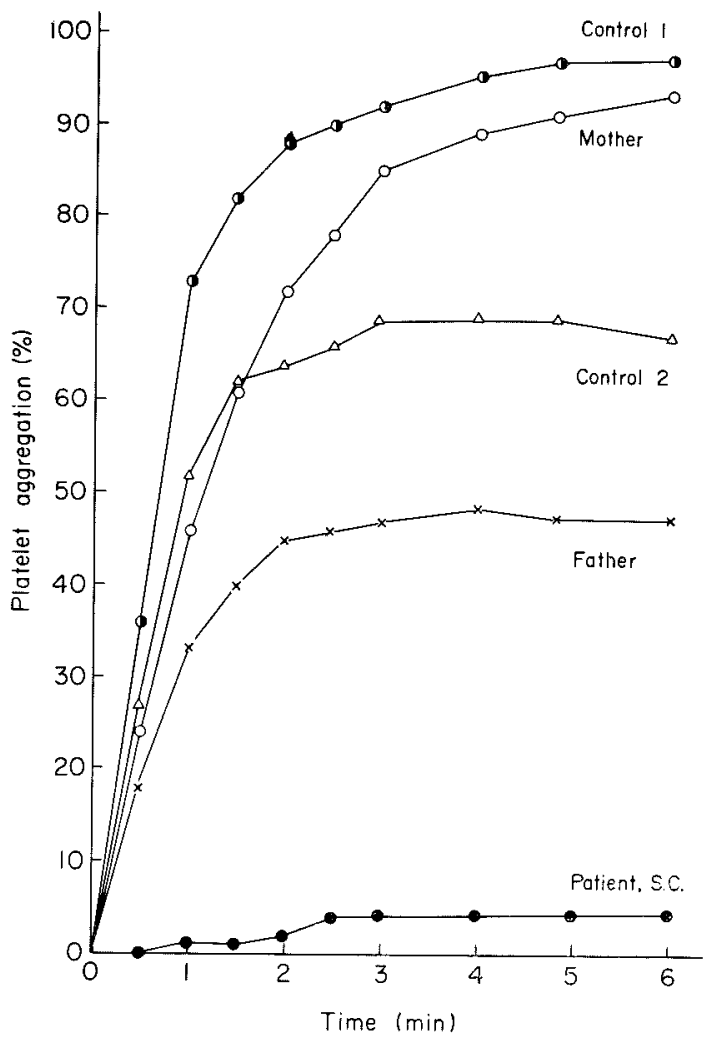

Fig. 1. Platelet aggregation by ADP in the present patient, her parents and two normal controls.

abnormal. The platelets of patient failed to aggregate normally in response to ADP* or collagen (Bovine Achilles tendon*) (cf. Fig. 1 and Table 1).

Family studies: The parents of the present case were studied with respect to platelet status and the results were normal except for the $\mathrm{H}_{2} \mathrm{O}_{2}$ induced aggregation of father's platelets as shown in Table 1 (cf. Table 1).

\section{Special Investigation}

Platelet aggregation induced by hydrogen peroxide $\left(\mathrm{H}_{2} \mathrm{O}_{2}\right)$

\section{Materials and Method}

Blood specimens were collected by venipuncture through a disposable needle into a plastic syringe and was immediately transferred to a silicone-coated centrifuge tube, containing $10 \%$ by volume of $3.8 \%$ sodium citrate solution, capped with parafilm and was mixed by inversion. Platelet-rich plasm (RPR) was prepared by centrifuging blood for 8 to 10 minutes at about $1,200 \mathrm{rpm}$ and platelet-poor plasm (PRP) by centrifuging for 30 minutes at $3,000 \mathrm{rpm}$ at $4^{\circ} \mathrm{C}$.

Platelet counts were done by the use of Rees-Ecker diluting fluid. The PRPs of

* ADP and collagen were acquired from Tokyo Kasei Kogyo Co. 
various platelet counts were prepared by diluting the original PRP with the PPP.

In the standard method, the PRP containing about 300,000 of platelets per cmm was used, unless indicated otherwise.

The erythrocyte content, if any, in the original PRP was less than 4,000 per $\mathrm{cmm}$.

Imidazole buffer was prepared by the method described by Mustard et al. (1964).

The solutions of hydrogen peroxide $\left(\mathrm{H}_{2} \mathrm{O}_{2}\right)$, adenosine*, reduced glutathione (GSH $\dagger$ ), $\mathrm{N}$-ethyl maleimide (NEM $\dagger$ ) and disodium ethylenediaminetetraacetate (EDTA) were made up in the imidazole buffer solution, $\mathrm{pH} 7.3$ (IBS).

The platelet aggregation was measured in a platelet aggregation meter, EEL 169 (Evans Electroselenium Ltd., Halstead, Essex, England) and recorded on a recorder (Model N-14, Rikadenki Koygo Co., Tokyo).

In the standard method used in the present investgation, $0.03 \mathrm{ml}$ of IBS or the test substance was added to $0.6 \mathrm{ml}$ of PRP and platelet aggregation was initiated by the addition of $0.07 \mathrm{ml}$ of $0.3 \% \quad \mathrm{H}_{2} \mathrm{O}_{2}$ solution. $\mathrm{H}_{2} \mathrm{O}_{2}$ solution was added by the use of a microsyringe (Hamilton, Type 1710).

The percent change in platelet aggregation at various time intervals were determined by the method described by Corby et al. (1971).

Platelet aggregation was also observed macroscopically and microscopically. In this case the same reaction mixture as described above in a siliconized test tube was vigorously shaken manually and was observed macroscopically. Aliquotes of the reaction mixture were taken out at time intervals and drawn into the leucocyte pipet up to the mark 0.5 and then the Rees-Ecker fluid was drawn up to the mark 101, mixed well, and then transfered to a counting chamber and subjected to a microscopic observation.

\section{RESULTS}

Normal platelets did aggregate very readily in response to $\mathrm{H}_{2} \mathrm{O}_{2}$, while the platelets from the present patient did not (cf. Table 1 and Figs. 2-4).

Platelets from the mother of the present case showed a normal aggregation by $\mathrm{H}_{2} \mathrm{O}_{2}$, while platelets from the father tended to show a low normal or slightly decreased aggregation (cf. Table 1 and Fig. 4).

The $\mathrm{H}_{2} \mathrm{O}_{2}$ induced aggregation of normal platelets reached at maximum levels during a period of time between one and one and a half minute after addition of $\mathrm{H}_{2} \mathrm{O}_{2}$ and then, in most cases, partly dispersed or disaggregated, as was shown in Fig. 2.

The maximum degree of aggregation by $\mathrm{H}_{2} \mathrm{O}_{2}$ of platelets from 11 normal control cases ranged from 20 to $67 \%$ and $46 \pm 3 \%$ in average (Table 2).

The aggregation and disaggregation of normal platelets were also confirmed by serial macroscopic and microscopic observation, by the use of method described above, of the mixture of $\mathrm{PRP}$ and $\mathrm{H}_{2} \mathrm{O}_{2}$ during a period of time between one and five minutes following the addition of $\mathrm{H}_{2} \mathrm{O}_{2}$.

\section{Relation between platelet aggregation and concentration of $\mathrm{H}_{2} \mathrm{O}_{2}$}

When the concentration of $\mathrm{H}_{2} \mathrm{O}_{2}$ was increased from $0.1 \%$ to $0.3 \%$, (or from $0.01 \%$ to $0.03 \%$ in the final concentration), the extent of platelet aggregation was also increased. But when the concentration of $\mathrm{H}_{2} \mathrm{O}_{2}$ was further increased from $0.3 \%$ to $0.5 \%$ or $1 \%$, the maximum percentage of platelet aggregation was not

* Merck Co.

† Tokyo Kasei Kogyo Co. 


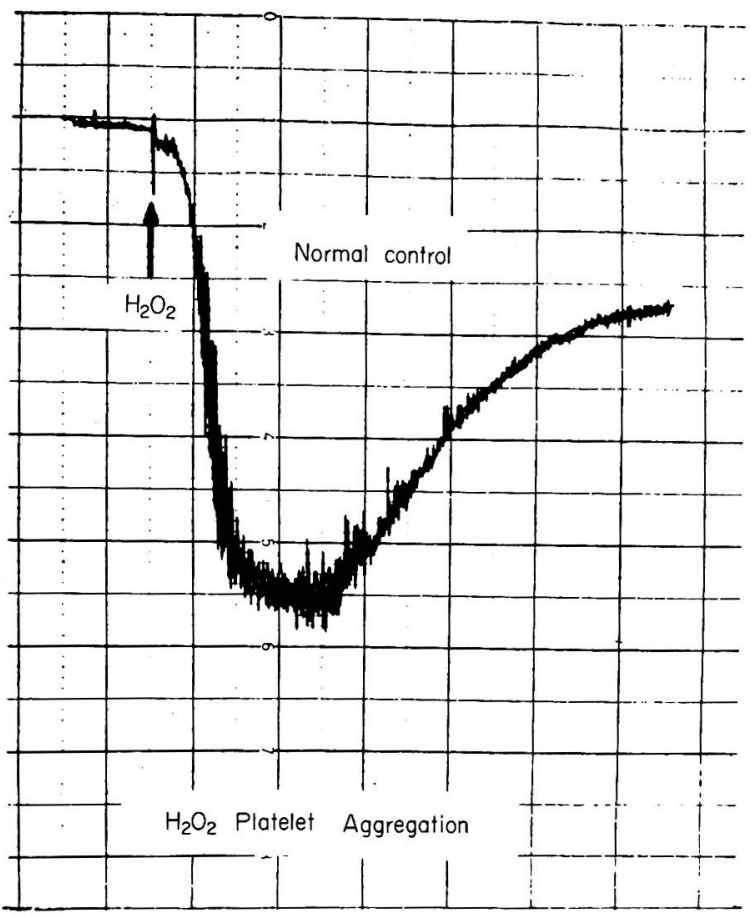

Fig. 2. A record by the aggregation meter of a normal platelet aggregation by $\mathrm{H}_{2} \mathrm{O}_{2}$ in a control case.

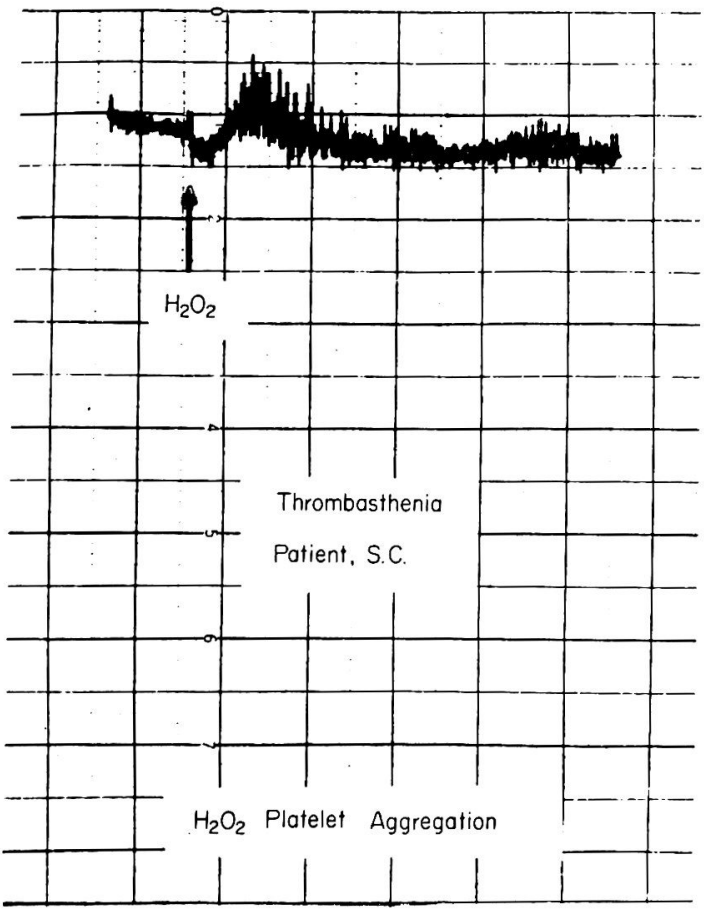

Fig. 3. A record by the aggregation meter of the absent platelet aggregation by $\mathrm{H}_{2} \mathrm{O}_{2}$ in the present patient. 


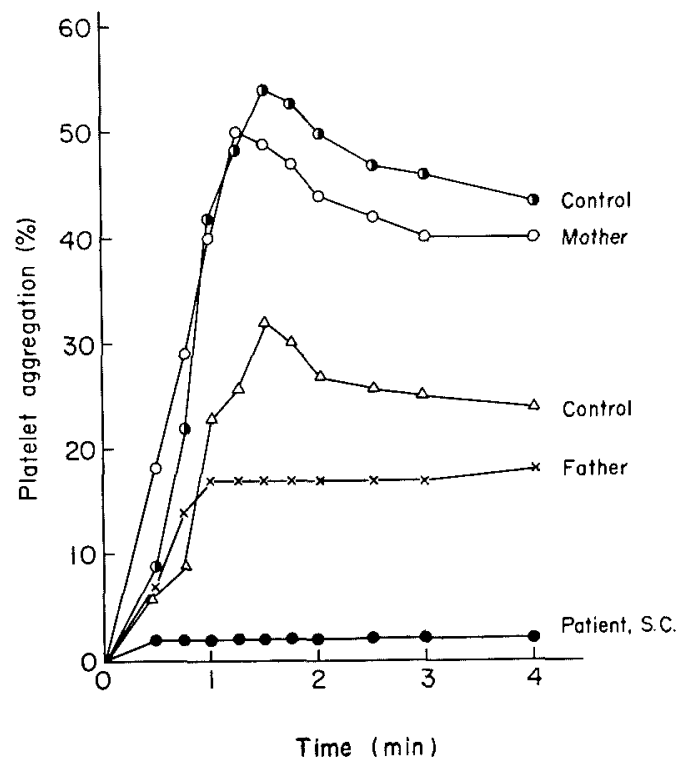

Fig. 4. Platelet aggregation by $\mathrm{H}_{2} \mathrm{O}_{2}$ in the present patient, her parents and two normal controls.

TABLE 2. The maximum levels of platelet aggregation by $\mathrm{H}_{2} \mathrm{O}_{2}$ in control cases

\begin{tabular}{|c|c|c|c|c|c|}
\hline No. & Name & Age & Sex & Clinical conditions & $\begin{array}{c}\text { Maximum platelet } \\
\text { aggregation } \\
\text { by } \mathrm{H}_{2} \mathrm{O}_{2}(\%)\end{array}$ \\
\hline 1. & N.J. & $15 \mathrm{y}$ & $\mathrm{F}$ & Apparently healthy & 48 \\
\hline 2. & H.O. & $48 \mathrm{y}$ & M & Apparently healthy & 42 \\
\hline 3. & N.K. & $9 y$ & M & Apparently healthy & 20 \\
\hline 4. & S.A. & $30 y$ & $\mathbf{F}$ & Apparently healthy & 54 \\
\hline 5. & O.K. & $13 \mathrm{y}$ & $\mathbf{M}$ & Upper respiratory infection & 32 \\
\hline 6. & S.Y. & $21 \mathrm{y}$ & $\mathrm{F}$ & Apparently healthy & 30 \\
\hline 7. & H.Y. & $20 y$ & $\mathbf{F}$ & Apparently healthy & 62 \\
\hline 8. & W.K. & $20 \mathrm{y}$ & $\mathbf{F}$ & Apparently healthy & 54 \\
\hline 9. & I.M. & $20 \mathrm{y}$ & $\mathbf{F}$ & Apparently healthy & 46 \\
\hline 10. & I.Y. & $20 \mathrm{y}$ & $\mathbf{F}$ & Apparently healthy & 67 \\
\hline 11. & H.T. & $24 \mathrm{y}$ & $\mathbf{F}$ & Apparently healthy & 56 \\
\hline
\end{tabular}

$\operatorname{Mean} \pm$ S.D. $=46 \pm 3$

always increased and could conversely be decreased as shown in Fig. 5.

Relation between platelet count and platelet aggregation by $\mathrm{H}_{2} \mathrm{O}_{2}$

As is shown in Fig. 6, there is a tendency that as the platelet count in PRP decreases the maximum per cent aggregation of platelets also decreases.

On the basis of such observation it was decided, as described already, to use PRP with a constant platelet count of about 300,000 per cmm of PRP, whenever possible, for the present $\mathrm{H}_{2} \mathrm{O}_{2}$ induced platelet aggregation test. 


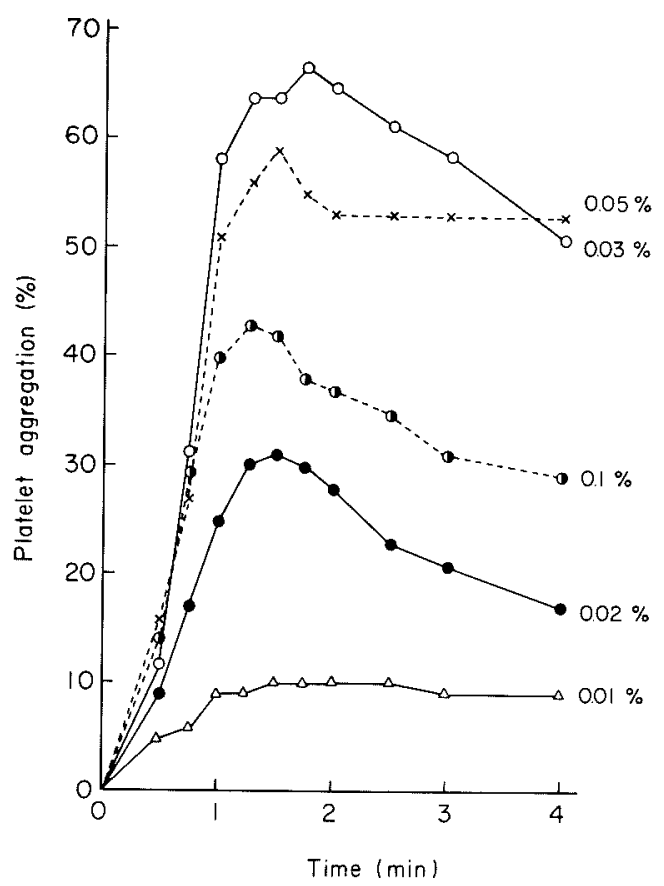

Fig. 5. Platelet aggregation by $\mathrm{H}_{2} \mathrm{O}_{2}$, varying 0.01 to $0.1 \%$ in a final concentration.

Effect of adenosine on the platelet aggregation by $\mathrm{H}_{2} \mathrm{O}_{2}$

$0.03 \mathrm{ml}$ of adenosine solutions of various concentrations, i.e. $0.2,0.4$ and 1 $\mathrm{mM}$, respectively, was added to $0.6 \mathrm{ml}$ of PRP and the mixture was incubated at $37^{\circ} \mathrm{C}$ for 5 minutes, and then $0.07 \mathrm{ml}$ of $0.3 \% \mathrm{H}_{2} \mathrm{O}_{2}$ solution was added to initiate platelet aggregation.

The inhibitory effect of adenosine on the platelet aggregation by $\mathrm{H}_{2} \mathrm{O}_{2}$ was clearly demonstrated as was shown in Fig. 7.

Effect of $\mathrm{N}$-ethylmaleimide (NEM) on the platelet aggregation by $\mathrm{H}_{2} \mathrm{O}_{2}$

To $0.6 \mathrm{ml}$ of PRP, either $0.03 \mathrm{ml}$ of IBS or $0.03 \mathrm{ml}$ of $70 / 3 \mathrm{mM}-\mathrm{NEM}$ or 0.015 $\mathrm{ml}$ of $140 / 3 \mathrm{mM}$-GSH and $0.015 \mathrm{ml}$ of $140 / 3 \mathrm{mM}-\mathrm{NEM}$, or $0.015 \mathrm{ml}$ of $140 \mathrm{mM}$-GSH and $0.015 \mathrm{ml}$ of $140 / 3 \mathrm{mM}-\mathrm{NEM}$ was added, and the mixture was incubated at $37^{\circ} \mathrm{C}$ for 1 minute and then $0.07 \mathrm{ml}$ of $0.3 \% \mathrm{H}_{2} \mathrm{O}_{2}$ solution was added.

The results showed that platelet aggregation by $\mathrm{H}_{2} \mathrm{O}_{2}$ was inhibited by NEM in a final concentration of $1 \mathrm{mM}$ and this inhibition by NEM was prevented by the addition of GSH in a final concentration of $3 \mathrm{mM}$ (Fig. 8).

Effect of disodium ethylenediaminetetraacetate (EDTA)

Effects of EDTA on the aggregation of platelets in citrated PRP induced by $\mathrm{H}_{2} \mathrm{O}_{2}$ were shown in Fig. 9. EDTA exerted its inhibitory effect on platelet aggregation in final concentrations of 1 to $10 \mathrm{mM}$. 


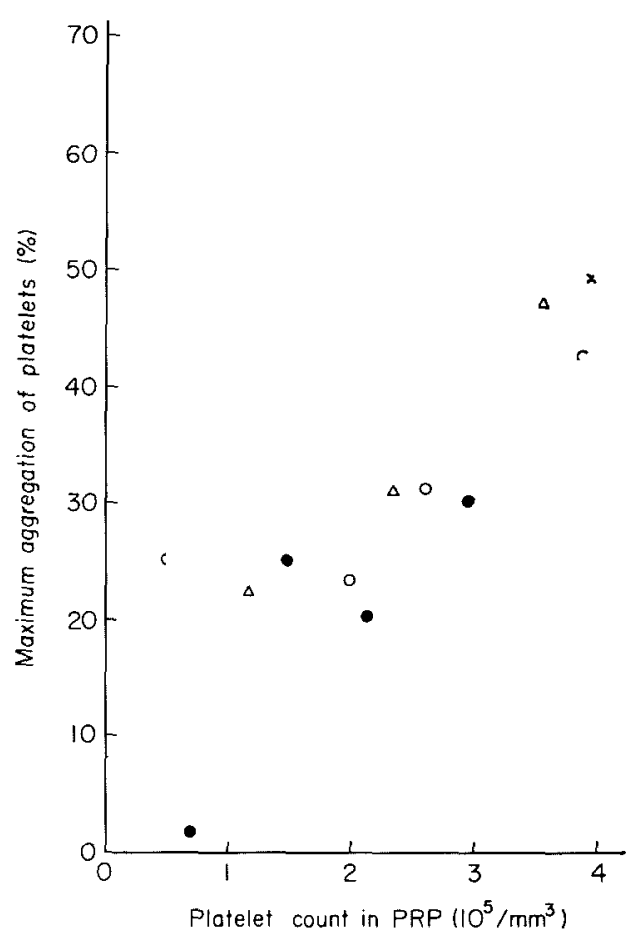

Fig. 6. Relationship between platelet count in PRP and platelet aggregation by $\mathrm{H}_{2} \mathrm{O}_{2}$.

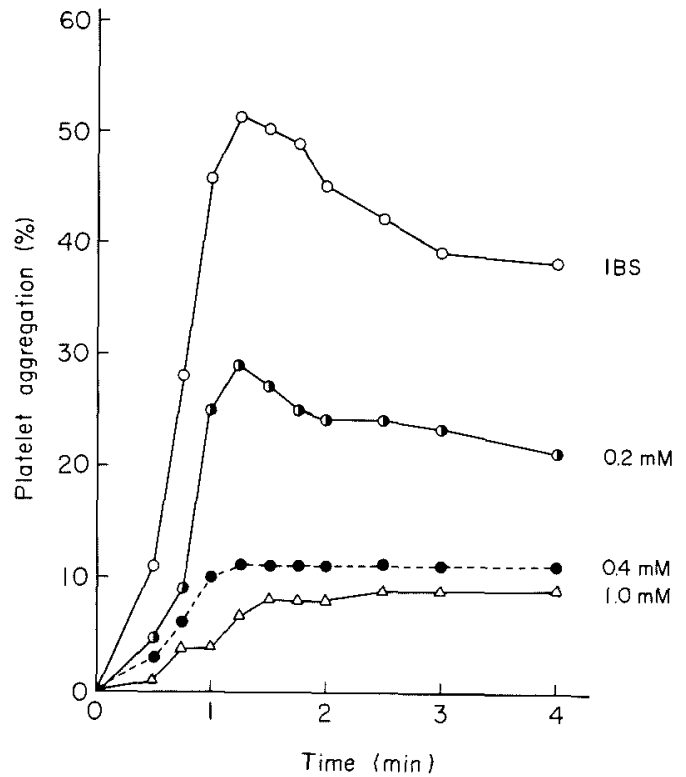

Fig. 7. The inhibitory effect of adenosine, of various concentrations in the solution added, upon the platelet aggregation by $\mathrm{H}_{2} \mathrm{O}_{2}$. For details, see text. 


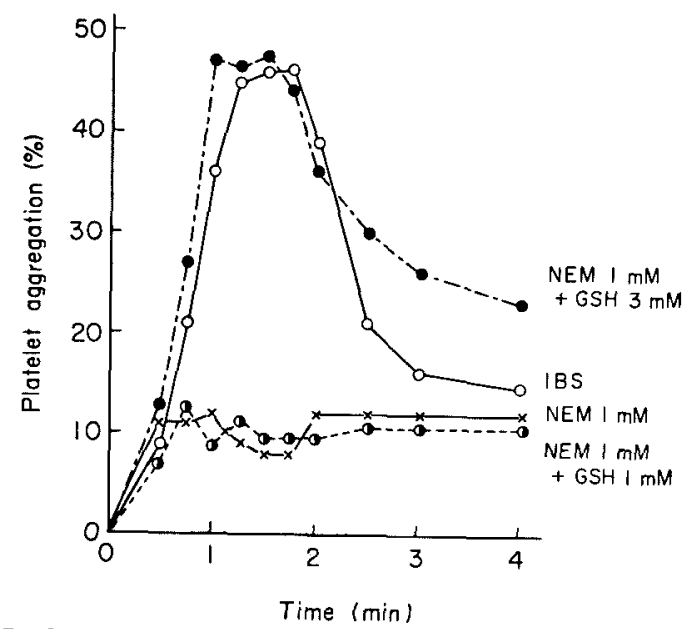

Fig. 8. Effects of $\mathrm{N}$-ethyl maleimide (NEM), with or without addition of reduced glutathione (GSH), upon the platelet aggregation by $\mathrm{H}_{2} \mathrm{O}_{2}$. For details, see text.

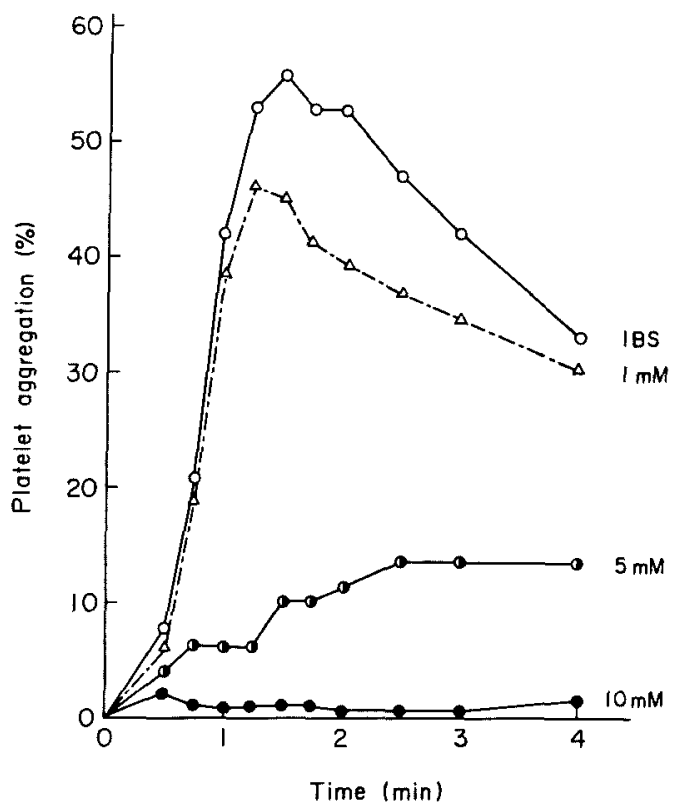

Fig. 9. The nhibitory effect of disodium ethylenediaminetetraacctate (EDTA), varying 1 to $10 \mathrm{mM}$ in a final concentration, upon the platelet aggregation by $\mathrm{H}_{2} \mathrm{O}_{2}$.

\section{Discussion}

The present case has shown a congenital bleeding tendency with normal platelet count, long bleeding time, decreased platelet adhesiveness to glass, abnormal thrombelastogram and absent platelet aggregation after the addition of ADP and collagen, and thus fulfills the diagnostic criteria of thrombasthenia (Hardisty et al. 1964, Zucker et al. 1966, Corby et al. 1971 and Hathway 1971). 
The basic defect in this disese appears to be the failure of platelets to aggregate in the presence of ADP. It is generally accepted that ADP plays a central role in platelet aggregation (Gaarder et al. 1961, Born 1962 and Käser-Glanzmann et al. 1962).

A variety of substances, including trypsin, serotonin, epinephrine, norepinephrine, and such particulate or semiparticulate substances as long-chain saturated fatty acids, protein-coated polystyrene particles, antigen-antibody complexes, heat-denatured plasma proteins, uric acid crystals, certain bacteria and viruses and glass beads, are known to be able to induce platelet aggregation. It has been posturated that ADP provides a final common pathway for all these agents (Marcus 1969).

The platelet aggregation brought about by ADP can be inhibited by adenosine (Born et al. 1963, Mustard et al. 1964 and O'Brien et al. 1966).

To our knowledge, there is no literature dealing with the platelet aggregation induced by hydrogen peroxide $\left(\mathrm{H}_{2} \mathrm{O}_{2}\right)$, and the present paper may be a first to describe such a phenomenon.

The exact mechanism underlying the phenomenon of platelet aggregation induced by $\mathrm{H}_{2} \mathrm{O}_{2}$ is obscure. But, the fact that the normal platelets preincubated with adenosine failed to aggregate in response to $\mathrm{H}_{2} \mathrm{O}_{2}$, as demonstrated in the present investigation, has suggested that $\mathrm{H}_{2} \mathrm{O}_{2}$ might stimulate the platelets to release $\mathrm{ADP}$, which in turn made platelets aggregate.

If this is the case, it seems conceivable that the platelets of the present patient of thrombasthenia could not be aggregated not only by $\mathrm{ADP}$ but also by $\mathrm{H}_{2} \mathrm{O}_{2}$. The problem that how $\mathrm{H}_{2} \mathrm{O}_{2}$ does affect, if any, ADP metabolism in platelet remains to be elucidated.

Platelet aggregation by ADP is dependent on calcium (Born and Cross 1963, Harrison, Emmons and Mitchell 1966) and thiol groups of platelets are involved in the process of aggregation (Robinson, Mason and Wagner 1963, Harrison, Emmons and Mithcell 1966). In these respects, the platelet aggregation by $\mathrm{H}_{2} \mathrm{O}_{2}$ appears bo be similar to that induced by ADP, as suggested by the results of present experiments using a chelating agent EDTA and a sulfhydryl inhibitor MEM. The possible role of calcium in the ADP platelet aggregation was discussed by Skålhegg et al. (1964).

\section{References}

1) Barry, A. \& Delage, J.M. (1965) Congenital deficiency of fibrin-stabilizing factor. New Eng. J. Med., 272, 943-946.

2) Biggs, R. \& Macfarlane, R.G. (1957) Human Blood Coagulation and its Disorders. Second ed., Charles C. Thomas, Springfield, Illinois.

3) Born, G.V.R. (1962) Aggregation of blood platelets by adenosine diphosphate and its reversal. Nature, 194, 927-929.

4) Born, G.V.R. \& Cross, M.J. (1963) The aggregation of blood platelets. J. Physiol., 168, 178-195.

5) Caen, J.P., Castaldi, P.A., Leclere, J.C., Inceman, S., Larrieu, M.J., Probst, M. \& Bernard, J. (1966) Congenital bleeding disorders with long bleeding time and 
normal platelet count. I. Glanzmann's thrombasthenia (Report of fifteen patients). Amer. J. Med. 41, 4-26.

6) Corby, D.G., Zirbel, C.L., Lindley, A. \& Schulman, I. (1971) Thrombasthenia. Amer. J. Dis. Child., 121, 140-144.

7) Didisheim, P. cited in M.M. Wintrobe, (1967) Clinical Hematology, Sixth ed., Lea and Febiger, Philadelphia, p. 329.

8) Gaarder, A., Jonsen, J., Laland, S., Hellem, A. \& Owren, P.A. (1961) Adenosine diphosphate in red cells as a factor in the adhesiveness of human blood platelets. Nature, 192, 531-532.

9) Hardisty, R.M., Dormandy, K.M. \& Hutton, R.A. (1964) Thrombasthenia. Studies on three cases. Brit. J. Haemat., 10, 371-387.

10) Harrison, M.J.G., Emmons, P.R. \& Mitchell, J.R.A. (1966) The effect of sulphydryl and enzyme inhibitors on platelet aggregation in vitro. Thromb. Diath. Haemorrh., 16, $122-133$.

11) Hathaway, W.E. (1971). Bleeding disorders due to platelet dysfunction. Amer. J. Dis. Child., 121, 127-134.

12) Higashi, O., Arakawa, Ts., Narisawa, K., Yoshida, T., Karita, M., Honda, Y. \& Sanjo, M. (1971) Hypersegmentation of megakaryocytes in a folic-acid deficient child. Tohoku J. exp. Med., 104, 183-194.

13) Käser-Glanzmann, R. \& Lüscher, E.F. (1962) The mechanism of platelet aggregation in relation to hemostasis. Thromb. Diath. Haemorrh., 17, 480-490.

14) Marcus, A.J. (1969) Platelet function (First of three parts). New Eng. J. Med., 280, 1213-1220.

15) Mustard, J.F., Hegardt, B., Roswell, H.C. \& MacMillan, R.L. (1964) Effect of adenosine nucleotides on platelet aggregation and clotting time. J. Lab. clin. Med., 64, 548-559.

16) O'Brien, J.R. (1966) Platelet stickiness. Ann. Rev. Med., 17, 275-290.

17) Robinson, C.W., Jr., Mason, R.G. \& Wanger, R.H. (1963) Effect of sulfhydryl inhibitors on platelet agglutinability. Proc. Soc. exp. Biol. Med., 113, 857-860.

18) Skålhegg, B.A., Hellme, A.J. \& Ödegaard, A.E. (1964) Investigations on adenosine diphosphate (ADP) induced platelet adhesiveness in vitro. Part II. Studies on the mechanism. Thromb. Diath. Haemorrh., 11, 305-316.

19) Tanaka, R. (1957) A study on the function, especially adhesiveness, of blood platelets. Acta haem. jap., 20, 270-282.

20) Zucker, M.B., Pert, J.H. \& Hilgartner, M.W. (1966) Platelet function in a patient with thrombasthenia. Blood, 28, 524-534. 